\title{
EHMTI-0149. Low CSF hypocretin-1 levels are associated with cluster headache
}

\author{
M Barloese ${ }^{1 *}$, P Jennum², N Lund ${ }^{1}$, S Knudsen ${ }^{2}$, S Gammeltoft ${ }^{3}$, R Jensen ${ }^{1}$ \\ From 4th European Headache and Migraine Trust International Congress: EHMTIC 2014 \\ Copenhagen, Denmark. 18-21 September 2014
}

\section{Background}

Cluster headache $(\mathrm{CH})$ is a debilitating headache disorder with strong chronobiological features characterized by severe pain attacks often waking the patient from sleep. Hypocretin (HCRT) is involved in the regulation of arousal and pain and is produced in the hypothalamus. HCRT has been suggested to play a role in the pathology of $\mathrm{CH}$.

\section{Aim}

To investigate HCRT-1 levels in $\mathrm{CH}$ during active bout.

\section{Methods}

CSF HCRT was measured in 12 chronic and 14 episodic $\mathrm{CH}$ patients during active bout, and in 27 healthy controls. Patients were characterized beyond the dichotomy of current diagnostic criteria (episodic/chronic) using a $\mathrm{CH}$ index reflecting total headache duration and their attack rhythmicity compared to HCRT concentrations.

\section{Results}

We found lower HCRT-1 levels in both chronic $(388.67 \mathrm{pg} / \mathrm{ml}, \mathrm{p}=0.0221)$ and episodic cluster headache $(375.36 \mathrm{pg} / \mathrm{ml}, \mathrm{p}=0.0005)$ compared with controls $(430.96 \mathrm{pg} / \mathrm{ml})$ and a tendency towards relatively higher values in chronic $\mathrm{CH}$ compared with episodic $\mathrm{CH}$. A positive relationship between the $\mathrm{CH}$ index and HCRT concentrations was found in all patients $(\mathrm{R} 2=$ $0.1541, \mathrm{p}=0.0473)$. We also identified a tendency towards relatively higher HCRT concentrations in patients without chronological rhythmicity.

\section{Conclusion}

This is the first report of lower HCRT-1 concentrations in $\mathrm{CH}$ suggesting that decreased levels may reflect an

${ }^{1}$ Neurology, Danish Headache Center, Glostrup, Denmark

Full list of author information is available at the end of the article insufficient anti-nociceptive activity of the hypothalamus. The exact mechanism of the anti-nociceptive effect of HCRT is not known and requires further investigation. In conclusion, this study supports the hypothesis of a connection between arousal- and pain- regulation and the pathogenesis of $\mathrm{CH}$.

No conflict of interest.

\section{Authors' details}

${ }^{1}$ Neurology, Danish Headache Center, Glostrup, Denmark. ${ }^{2}$ Neurology, Danish Center for Sleep Medicine, Glostrup, Denmark. ${ }^{3}$ Diagnostics, Clinical Biochemistry Section, Glostrup, Denmark.

Published: 18 September 2014

doi:10.1186/1129-2377-15-S1-E14

Cite this article as: Barloese et al.: EHMTI-0149. Low CSF hypocretin-1 levels are associated with cluster headache. The Journal of Headache and Pain 2014 15(Suppl 1):E14.

\section{SpringerOpen ${ }^{\circ}$}

(C) 2014 Barloese et al; licensee Springer. This is an Open Access article distributed under the terms of the Creative Commons Attribution License (http://creativecommons.org/licenses/by/2.0), which permits unrestricted use, distribution, and reproduction in any medium, provided the original work is properly cited.
Submit your manuscript to a SpringerOpen ${ }^{\circ}$ journal and benefit from:

- Convenient online submission

- Rigorous peer review

- Immediate publication on acceptance

- Open access: articles freely available online

- High visibility within the field

Retaining the copyright to your article

Submit your next manuscript at $>$ springeropen.com 